Published in final edited form as:

Mol Nutr Food Res. 2018 January ; 62(1): . doi:10.1002/mnfr.201700621.

\title{
Regulation of Hedgehog Signaling in Cancer by Natural and Dietary Compounds
}

\author{
Cheng Bao ${ }^{1}$, Pavel Kramata ${ }^{2}$, Hong Jin Lee ${ }^{1,{ }^{*}}$, Nanjoo Suh ${ }^{2,3,{ }^{*}}$ \\ ${ }^{1}$ Department of Food Science and Technology, Chung-Ang University, Anseong, 17546, South \\ Korea \\ 2Department of Chemical Biology, Ernest Mario School of Pharmacy, Rutgers, The State \\ University of New Jersey, Piscataway, NJ 08854, USA \\ ${ }^{3}$ Rutgers Cancer Institute of New Jersey, New Brunswick, NJ 08903, USA
}

\begin{abstract}
The aberrant Hedgehog (Hh) signaling induced by mutations or overexpression of the signaling mediators has been implicated in cancer, associated with processes including inflammation, tumor cell growth, invasion and metastasis, as well as cancer stemness. Small molecules targeting the regulatory components of the Hh signaling pathway, especially Smoothened (Smo), have been developed for the treatment of cancer. However, acquired resistance to a Smo inhibitor vismodegib observed in clinical trials suggests that other Hh signaling components need to be explored as potential anticancer targets. Natural and dietary compounds provide a resource for the development of potent agents affecting intracellular signaling cascades, and numerous studies have been conducted to evaluate the efficacy of natural products in targeting the Hh signaling pathway. In this review, we summarize the role of Hh signaling in tumorigenesis, discuss results from recent studies investigating the effect of natural products and dietary components on Hh signaling in cancer, and provide insight on novel small molecules as potential Hh signaling inhibitors.
\end{abstract}

\section{Keywords}

Cancer; Hedgehog; Gli; Natural inhibitors; Smoothened

\section{Introduction}

The Hedgehog (Hh) signaling pathway was first identified in Drosophila [1]. It is known to be involved in various developmental processes such as tissue patterning and organogenesis during embryogenesis [2-4] as well as in tissue regeneration and repair after injury [5, 6]. Although Hh signaling is important during development, its dysregulation has been

\footnotetext{
"Co-corresponding authors: Nanjoo Suh, Ph.D., Department of Chemical Biology, Ernest Mario School of Pharmacy, Rutgers, The State University of New Jersey, Piscataway, NJ 08854, USA, Tel: +1-848-445-8030 Fax: +1-732-445-0687,

nsuh@pharmacy.rutgers.edu, Hong Jin Lee, Ph.D., Department of Food Science and Technology, Chung-Ang University, Anseong, 17546, South Korea, Tel: +82-31-670-3030, Fax: +82-31-675-4853, hongjin@cau.ac.kr.

Conflict of interest

The authors have no conflict of interest.
} 
implicated in hyperproliferative disorders including cancer [7-9]. Genetic mutations of $\mathrm{Hh}$ signaling mediators and their hyperactivation have been associated with development of basal cell carcinoma (BCC), medulloblastoma, breast, pancreatic, prostate and lung cancers [10]. Consequently, Hh signaling has been explored for cancer prevention and treatment [11, 12]. Clinical development of agents targeting a Hh signaling component Smoothened (Smo) resulted in approval of vismodegib and sonidegib for the treatment of BCC by the United States Food and Drug Administration (FDA) in 2012 and 2015, respectively. However, development of resistance to vismodegib reported in patients with advanced BCC and medulloblastoma $[13,14]$ underscores the need for alternative approaches targeting different mediators of the Hh signaling pathway.

Because of the role of the Hh signaling in cancer, naturally occurring compounds and dietary components inhibiting aberrant Hh signaling have been investigated for cancer prevention and therapy during the past decade $[15,16]$. We retrieved articles from the PubMed database using the keywords "hedgehog and cancer", "Smo and cancer", and "Gli and cancer" and searched for natural products and dietary components reported to regulate Hh signaling in cancer. In this article, we review the role of Hh signaling in processes associated with carcinogenesis, such as inflammation, tumor growth, invasion, metastasis and stemness. In addition, we summarize results from in vitro and in vivo studies investigating natural products and dietary components as inhibitors of Hh signaling.

\section{Hh Signaling}

Hh signaling is activated upon the interaction between Hh ligands, such as Sonic Hedgehog (Shh), Desert Hedgehog (Dhh), and Indian Hedgehog (Ihh), and the membrane-bound cell surface receptor, Patched (Ptch) $[17,18]$. In the absence of Hh ligands, Ptch keeps G protein-coupled receptor Smo from entering the primary cilium, where the suppressor of fused ( $\mathrm{SuFu}$ ) forms complex with glioma associated oncogene (Gli) 2 and 3 [19]. Gli can be phosphorylated by protein kinase A (PKA), casein kinase (CK)-1, and glycogen synthase kinase (GSK)-3 $\beta$ and partially degraded by proteasome in the base of the primary cilium [20-23]. Recently, the ciliary G-protein coupled receptor Gpr161 was found to increase the level of cAMP, resulting in PKA activation [24]. This observation suggests that cilia has a possible role in repressing Gli in the absence of Hh ligand, and in converting inactive Gli to an active form in the presence of the ligand. After partial removal of the C-terminal domain, the repressor form of Gli translocates to the nucleus to act as a transcriptional repressor to turn off Hh signaling.

During activation of the Hh signaling pathway, Hh ligands bind to the Ptch receptor to form a complex which is then degraded in lysosomes, and released Smo is relocalized at the tip of the cilium to activate downstream signaling [25]. Although the precise mechanism of Smo activation is not clearly understood, recent studies suggest that covalent modification of Smo on the Asp95 residue by cholesterol induce conformational changes in response to $\mathrm{Hh}$ ligands [26, 27]. After Smo activation, Gli2/3 escapes from SuFu complex and Gli2 as an activated form of Gli (Gli-A) induces transcription of the target genes. One of the target genes, Gli1, further amplifies the Hh signaling; Gli1 expression level has been suggested as an indicator of Hh signaling activity [28]. Other Gli targets include genes involved in cell 
proliferation (MYC, CCND1, CCND2, FOXM1)[29-32], stem cell regeneration (JAG2, FST) [30, 33], and cell survival (BCL2, c-FLIP) [34, 35].

In addition to the ligand and receptor-dependent mechanisms, Hh signaling mediators, especially Gli, are known to be regulated by different cellular networks including mitogenactivated protein kinases (MAPK), phosphatidylinositol-3-kinase (PI3K)/AKT, tumor necrosis factor (TNF)- $\alpha$, and transforming growth factor (TGF)- $\beta$ [36-41]. The activation of PI3K/AKT also leads to Gli1/2 up-regulation, where a Gli inhibitor and an AKT inhibitor synergistically suppress tumor growth in vitro and in vivo [40]. Recently, TNF-a was found to induce Gli1 phosphorylation through mammalian target of rapamycin (mTOR)/S6 kinase (S6K) 1 in esophageal adenocarcinoma [39]. Additionally, interaction of $\beta$-catenin with Gli1 and induction of Gli1/2 by TGF- $\beta$ through Smad3 were implicated in regulation of $\mathrm{Hh}$ signaling $[36,41]$. After it was reported that activated MEK1 induces the expression of the Gli protein, and the N-terminus of Gli1 is an important region for extracellular signalregulated kinase (ERK) 1/2 [37], interactions between Hh signaling and ERK1/2, ERK5, cJun N-terminal kinase (JNK), and p38 have been demonstrated in different cancers (reviewed in [42]).

\section{The role of Hh signaling in carcinogenesis}

The underlying mechanisms of Hh signaling in cancer development have been extensively reviewed [43] and include i) mutation-driven ligand-independent $\mathrm{Hh}$ activation in BCC and medulloblastoma; ii) ligand-dependent autocrine Hh activation in lung, breast, stomach, and prostate cancer, iii) ligand-dependent paracrine $\mathrm{Hh}$ activation in pancreatic cancer, iv) ligand-dependent inverse paracrine Hh activation in B-cell lymphoma, multiple myeloma, and leukemia [10]. Here, we discuss how Hh signaling is involved in the process of tumor development and metastasis.

\section{Hh signaling in inflammation}

Inflammation is known to be associated with cancer development by driving several processes including proliferation, angiogenesis, and metastasis [44]. Recent studies have shown that $\mathrm{Hh}$ signaling is activated during inflammation. In Helicobacter pylori-induced gastric inflammation, nuclear factor- $\kappa \mathrm{B}(\mathrm{NF}-\kappa \mathrm{B})$ is activated to induce gene expression of Shh, Ptch, and Gli $[45,46]$. Further, upregulated cytokines, such as IL-6, IL-1 $\beta$ and TNF- $a$, have been associated with uncontrolled activation of Hh signaling [47]. The inhibition of $\mathrm{Hh}$ signaling by a Smo inhibitor reduces activated macrophages and decreases the expression of pro-inflammatory molecules such as TNF- $\alpha$, IL-1 $\beta$ and IL-6 in hepatic inflammation [48]. These results indicate that $\mathrm{Hh}$ signaling is associated with inflammatory responses that contribute to carcinogenesis.

\section{Hh signaling in cancer cell growth}

Hh signaling regulates cell proliferation through modulating the cell cycle- and apoptosisrelated genes. In particular, cyclin D and cyclin E involved in the G1/S transition are known to be transcription targets of $\mathrm{Hh} / \mathrm{Gli}$ signaling in mammalian cells [49-51]. Ptch has been shown to regulate cyclin B/mitosis-promoting-factor (MPF) complex where MPF is required 
for the G2/M transition in most cell types [52]. Shh, an Hh ligand, blocks cyclin-dependent kinase inhibitor p21-induced cell cycle arrest [53]. In addition, Hh signaling enhances cell survival by inhibiting caspase 8 signaling through regulating cFLIP and FAS, as well as activating BCL2 promoter [34, 35, 54]. Recently, it was reported that Shh promotes tumor cell survival by inhibiting a Shh receptor, cell adhesion molecule-related/down-regulated by oncogenes (CDON) [55]. Hh signaling inhibitors, such as cyclopamine and vismodegib targeting Smo, and GANT (GLI ANTagonist) 61 targeting Gli, were reported to inhibit cell proliferation through cell cycle arrest and apoptosis in different cancer models [56-58].

\section{Hh signaling in angiogenesis}

Tumor progression requires the formation of new blood vessels to supply oxygen and nutrients mediated by vascular endothelial growth factor (VEGF) signaling [59]. Activation of the Hh pathway was found to enhance vascularization by regulating VEGF and VEGF receptor in triple negative breast cancer [60, 61] and hepatocellular carcinoma [62]. Ectopic overexpression of Shh in colon xenografts increased tumor blood vessel density and angiogenesis via Hh-induced VEGF [63]. Harris et al. reported that constitutive expression of Shh enhanced vascularization in breast cancer by upregulating a Hh signaling target gene, cysteine-rich angiogenic inducer 61 (cyr61), although in a VEGF-independent mechanism [64]. Overall, these results suggest an important role of Hh signaling in regulating angiogenesis.

\section{Hh signaling in invasion and metastasis}

Tumors metastasize by invading the basement membrane, extravasating into circulatory system including lymph and blood vessels, and intravasating to distant locations [65]. Gli1 was found to directly bind the promoter region of human CXCR4 gene and stimulate ERK phosphorylation in breast cancer which results in cellular invasiveness and metastasis [66]. Further, TNF- $a$ induced Gli1 expression increased the migration and invasion of breast cancer cells by activating MMP-9 [67]. In gastric cancer, Shh activated PI3K/AKT signaling and enhanced cellular motility and invasiveness [68]. Chong et al reported that galectin-1, which stimulates invasiveness of gastric cancer, increased the expression of Gli1 independently of Smo and further promoted metastasis [69]. In glioblastoma, Shh dosedependently upregulated the expression of MMP-2 and MMP-9, leading to enhanced cell migration and invasion [70].

\section{Hh signaling in cancer stem cells}

Cancer stem cells (CSC) have been functionally defined by their capacity to undergo selfrenewal and differentiation that may participate in tumor relapse and drug resistance [71]. The involvement of Hh signaling in CSC has been suggested in studies of multiple human cancers (reviewed in [72]). Activated Hh signaling in CSC was found in glioblastoma [73], breast cancer [74], colon cancer [75], and pancreatic cancer [76], where the suppression of Hh mediators by inhibitors, a ligand-neutralizing antibody, and/or siRNA treatment resulted in inhibition of stem-like properties. Hh signaling is activated in Bcr-Abl positive leukemia stem cells (LSC), and pharmacological inhibition of Smo reduced LSC in vivo [77], suggesting that Smo inhibition could be an effective treatment strategy in reducing tumor relapse and drug resistance in chronic myeloid leukemia. 


\section{Regulation of Hh signaling by natural and dietary compounds}

Natural and dietary compounds generally target multiple signaling pathways and are not known to be specific or direct modulators of individual signaling pathways. Only a limited number of studies have attempted to identify direct molecular targets of natural and dietary compounds in Hh signaling. However, it may be worth the effort because natural compounds often uncover novel mechanisms or chemical structures that are useful as platforms for drug development. Here, we provide an overview of studies with natural and dietary compounds active in modulating the Hh signaling pathway. The studies use both non-specific tumor models as well as models specific to molecules involved in Hh signaling pathways. The effects of natural products and dietary components reported to inhibit Hh signaling from in vitro and in vivo studies are summarized in Tables 1 and 2, respectively.

\subsection{Direct inhibitors of Hh signaling from natural and dietary sources}

Berberine-This isoquinoline alkaloid from the Berberis species was reported to suppress Gli1 transcriptional activity induced by a Shh ligand or a Smo agonist (SAG) [78]. Berberine inhibited Hh signaling activity by targeting Smo, most likely by directly binding to Smo on the same site as cyclopamine, and suppressesed Hh-dependent medulloblastoma growth in vitro and in vivo [78].

Cyclopamine and jervine-Cyclopamine and jervine, natural steroidal alkaloids isolated from Veratrum californicum, are the first small molecule Hh inhibitors identified to bind to the transmembrane domain of Smo [79]. Jervine, a metabolically more stable analog of cyclopamine, is 5- to 10-fold less potent in inhibiting Smo than cyclopamine [80]. As a lead natural Smo inhibitor, cyclopamine suppressed tumor growth in animal models [75, 81-84], and topical application of cyclopamine regressed BCC development in patients [85].

However, its insolubility in water, poor stability, and relatively high toxicity led to the development of pharmacologically more useful inhibitors [86-88]. Based on the mechanisms targeting the transmembrane domain of Smo, two novel synthetic Smo inhibitors, vismodegib and sonidegib, were developed and recently approved by the FDA for the treatment of locally advanced or metastatic BCC $[89,90]$. Since cyclopamine and related compounds have been extensively described as inhibitors of Hh signaling in recent literature, we limit discussion on these compounds in this review.

Glabrescione B-Glabrescione B, identified from the seeds of Derris glabrescens, was recently shown by NMR spectroscopy to directly interact with K340 and K350 in zinc finger (ZD) domain 4 of Gli1. Because ZD4 and ZD5 domains of Gli1 can bind to a specific sequence of DNA, glabrescione B interferes with Gli1/DNA binding resulting in impairment of Gli1-dependent transcriptional activity. In biological assays, glabrescione B suppressed Gli1 target genes in Gli1-overexpressed HEK293T cells, $\mathrm{Smo}^{-1-}$ mouse embryonic fibroblasts (MEF), $\mathrm{Ptch}^{-1-} \mathrm{MEF}$ and $\mathrm{SuFu}^{-/-} \mathrm{MEF}$ cells [91]. In allograft animal models where primary medulloblastoma cells from $\mathrm{Ptch}^{+/-}$mice and Gli1-dependent BCC cells (ASZ001) were grafted, glabrescione B inhibited tumor growth and decreased the expression of Gli1 and its target genes [91]. 
Vitamin D3-Bijlsma et al. first reported that vitamin D3 directly binds Smo at the same site as cyclopamine in yeast model transformed with Smo using Scatchard analysis, and its treatment of zebrafish embryos mimicked the $\mathrm{smo}^{-/-}$phenotype such as U-shaped somites and aberrant extension of the yolk tube [92]. From a structure-activity relationship study, Aring of vitamin D3 was important in direct binding to Smo and inhibiting Hh signaling [93, 94]. Vitamin D3 further showed inhibition of Hh signaling in BCC cells (ASZ) in a vitamin D receptor (VDR) independent way, and its topical application reduced Gli1 mRNA expression and proliferation of BCC cells in $\mathrm{Ptch}^{+/-}$K14-CreER p53 fl/fl mice [95]. In addition, in renal cell carcinoma, vitamin D3 inhibited cellular growth and suppressed the expression of Gli2, an effect that was diminished when Smo was not expressed [96]. Oral administration or intraperitoneal injection of vitamin D3 also suppressed tumor growth in the xenograft model and decreased the expression of Gli2 in tumor tissue lacking VDR [96]. Active form of vitamin D3, calcitriol, inhibited cell proliferation in vitro and growth of BCC in Ptch mutant mice by targeting Smo [97]. Although vitamin D3 and its metabolites were reported to inhibit Hh signaling in a VDR-independent manner [95-97], it was recently demonstrated that VDR enhances the expression of SuFu through regulating miR-214 in breast cancer cells [98]. Overall, these findings suggest the interplay between vitamin D/VDR axis and Hh signaling in cancer.

\subsection{Potential inhibitors of Hh signaling from natural and dietary sources}

Curcumin and bisdemethoxycurcumin-Curcumin, a main active ingredient of Curcuma Longa (turmeric), induced cell cycle arrest and apoptosis via down-regulating the Hh signaling mediators including Gli1 in medulloblastoma and glioma cells [99, 100]. It suppressed the transcriptional activity of Gli1 and inhibited growth of mouse prostate cancer cells [101]. Recently, several studies demonstrated that curcumin, via inhibiting the $\mathrm{Hh}$ signaling pathway, reversed epithelial-mesenchymal transition (EMT) induced by TGF- $\beta 1$ or hypoxia in pancreatic cancer cells [102, 103] and by $\gamma$-irradiation in glioma cells [104]. In a tumorsphere culture of lung CSC, curcumin suppressed formation of the tumorsphere and increased expression of stem cell markers, CD133, CD44, aldehyde dehydrogenase (ALDH) 1, Nanog, and Oct4, as well as expression of Gli and Smo, all of which were induced by Smo activator purmorphamine [105].

Epigallocatechin gallate (EGCG)_EGCG, a well-known catechin in green tea, was found to down-regulate the expression of Gli1 and inhibit the proliferation of mouse prostate cancer cells [101] and human chondrosarcoma cells [106]. In pancreatic CSC, EGCG inhibited cellular self-renewal capacity through regulating stem cell markers, Nanog, c-Myc and Oct4, as well as Hh signaling mediators, Smo, Ptch and Gli1/2 [107]. In an animal model of carcinogen-induced liver cancer, oral administration of EGCG reduced the population of a-fetoprotein- and CD44-positive cells and inhibited the expression of Gli1, Smo, cyclin D1, cMyc, and EGFR [108, 109].

Genistein and daidzein-Genistein, one of major isoflavones in soy products, inhibited transcriptional activity and expression of Gli1 in prostate cancer cells [101]. An additional study reported that genistein suppressed tumorsphere formation and decreased Gli1 and CD44 expression [110]. In a xenograft model of docetaxel-resistant prostate cancer cells, 
genistein inhibited tumor growth and down-regulated the expression of Gli1 and CD44 in tumor tissues whereas docetaxel showed no effect [110]. In MCF-7 breast cancer cells, genistein reduced the size and number of tumorspheres, decreased the percentage of the $\mathrm{CD} 44^{+} / \mathrm{CD} 24^{-}$subpopulation, and inhibited the expression of Smo and Gli1 [111]. This finding was further confirmed in MCF-7 xenograft tumors by demonstrating that genistein decreased tumor weight, and reduced the expression of Smo, Gli1, and a key stem cell marker ALDH1 [111]. Similar results showing regulation of Gli1 and CD44 expression and CSC properties by genistein were reported from a study of gastric cancer [112]. Another isoflavone, daidzein, was found to reverse cellular migration and invasion stimulated by TNF- $a$ via inhibiting Gli1 expression and its transcriptional activity as well as MMP-9 activity in estrogen receptor (ER)-negative breast cancer cells [67].

Resveratrol-The compound, a stilbenoid found in grapes, blueberries and peanuts, inhibits Gli1 transcriptional activity [101]. Recent studies demonstrated resveratrol-mediated suppression of proliferation and induction of apoptosis in pancreatic cancer by modulating the expression of Gli1, Ptch and Smo [113]. Resveratrol inhibited the invasion capacity of gastric cancer cells by blocking the expression of Gli1, Snail, and N-cadherin and by increasing levels of E-cadherin [114]. In addition, hypoxia-stimulated Hh activation and invasiveness was suppressed by resveratrol in pancreatic cancer cells [115]. It is noteworthy that all studies of resveratrol targeting the Hh signaling have been conducted in cultured cells but not in vivo.

Silibinin-The compound present in seeds of milk thistles inhibited cell proliferation, induced apoptosis, and reduced Gli1 expression in renal cell carcinoma cells [116]. Silibinin decreased expression of phosphorylated AKT, mTOR, Gli1 and BCL2 in a renal cell carcinoma xenograft model [116]. Importantly, it is recently reported that silibinin inhibited the growth of Smo inhibitor-resistant basal cell carcinoma cells via targeting EGFR-MAPKAKT, suggesting the possible combination of Smo inhibitors and other Hh targeting natural molecules [117].

Sulforaphane and sulforaphene-Sulforaphane, commonly found in cruciferous vegetables, suppressed the expression of Smo and Gli as well as Nanog and Oct4 in pancreatic cancer cells, which may indicate depletion of CSC [118]. A subsequent study using a xenograft model implanted with $\mathrm{CD} 133^{+} / \mathrm{CD} 44^{+} / \mathrm{CD} 24^{+} / \mathrm{ESA}^{+}$pancreatic CSC showed that oral administration of sulforaphane inhibited tumor growth and expression of Smo, Gli, Nanog, and Oct4 [119]. A sulforaphane analog, sulforaphene, was also found to inhibit Hh signaling mainly through reducing Gli1 expression and altering its localization which resulted in decreased migration and invasion of breast cancer cells [120].

Zerumbone and gedunin-Zerumbone, a sesquiterpene identified from the subtropical ginger Zingiber zerumbet, was reported to suppress the expression of chemokine receptor 4 (CXCR4) [121], a direct target of Gli1 involved in migration and metastasis of breast cancer cells [66]. These results suggest that zerumbone may regulate metastasis through Gli1/ CXCR4 in breast cancer. Gedunin, a tetranotriterpenoid identified from Azadirachta indica known as Neem, inhibited proliferation, migration and metastasis of pancreatic cancer cells 
and reduced both endogenous and Shh-stimulated levels of Ptch, Smo, Gli1, Shh, and SuFu [122]. Gedunin also reduced tumor growth in a xenograft model and decreased the levels of Hh mediators and EMT markers such as Notch-2, Snail, N-cadherin and Vimentin [122].

Others-Ishibashi et al employed a tetracyclin-regulated Gli1 expression/Gli1-luciferase assay system in $\mathrm{HaCaT}$ cells to screen the effects of natural components on Hh signaling and further to test their growth inhibitory effects in pancreatic (PANC1) and prostate (DU145) cancer cells [123-129]. The compounds identified as suppressors of Gli1 expression and transcriptional activity and inhibitors of cell proliferation included acoschimperoside P, 2'acetate from Vallaris glabra, betulinic acid and colubrinic acid from Zizyphus cambodiana, gitoxigenin analogues from Adenium obesum, taepeenin D, (+)-drim-8-ene and quercetin 3O-beta-D-glucopyranosyl-4-O-beta-D-glucopyranoside from Acacia pennata, staurosporinone and physalin F \& B from Crinum asiaticum, physalin H from Solanum nigrum, and vitetrifolin from Vitex negundo [123-129]. Arcyriaflavin C from Tubifera casparyi also suppressed the transcriptional activity of Gli1 without affecting cell viability [124]. Importantly, physalin $\mathrm{H}$ and vitetrifolin blocked the direct interaction between Gli1 and DNA containing Gli1 binding site, suggesting Gli as a molecular target [127, 128]. Deguelin, a natural rotenoid derived from plants including Derris trifoliate, was reported to up-regulate SuFu and Ptch1/2, down-regulate Gli1, and inhibit proliferation, migration, and invasion in pancreatic cancer cells [130]. Ellagic acid, produced by hydrolysis of tannins from different fruits and vegetables, inhibited pancreatic tumor growth when orally administered and suppressed the expression of Gli1 and Gli2 in tumor tissues [131]. It was recently reported that crocetinic acid purified from crocetin inhibited the sphere formation of pancreatic cancer cells and decreased the expression of Shh, Smo, Gli1 and SuFu [132]. Germacranolide, a sesquiterpene lactone from Siegesbeckia glabrescens, suppressed the expression of Gli1 and Gli1-luciferase activity in pancreatic cancer cells [133]. Apigenin, baicalein, and quercetin inhibited cell growth and Gli1 expression in TRAMP-C2 cells although they did not affect Shh-induced Gli transcriptional activity in Shh Light II cells [101]. Recently, Infante et al. employed in silico screening of an in house compound library against the crystallographic structure of Smo bound to cyclopamine [134]. Based on the virtual hits fitting the Smo binding site and interaction with Smo residues, N219, Y394, K395, R400 and E518, the Smo antagonists were selected by using the FRED docking program and by ranking the Chemgauss 4 score [134]. The biological function of selected molecules were then confirmed in Gli-responsive luciferase assay system, and isosophoranone, sorocein A, kuwanol E, and derrustone were found to exert an inhibitory activity [134]. Overall, modulation of the specific molecules in the Hh signaling pathway by natural and dietary inhibitors does not necessarily indicate that these compounds are specific or direct Hh inhibitors. The tumor inhibitory effects of these natural products and dietary components in the Hh-specific model systems need to be further examined to confirm whether molecular mechanisms involved are dependent on Hh signaling.

\section{Conclusion and Future Directions}

The role of Hh signaling in carcinogenesis has been demonstrated in experimental models and confirmed by clinical efficacy of two FDA-approved selective Smo inhibitors, 
vismodegib and sonidegib. However, the acquired resistance to vismodegib in cancer patients demonstrates clinical limits of targeting Smo and sheds light on the roles of different mediators of the Hh signaling pathway. As reviewed in this article, numerous studies have evaluated the effects of natural products and dietary components on $\mathrm{Hh}$ signaling through Smo, Gli, SuFu and other factors. Results from these studies can provide new insights into the development of promising agents for cancer prevention and treatment. However, there are several important issues to highlight before considering inhibition of $\mathrm{Hh}$ signaling by natural products and dietary components as a viable cancer preventive strategy.

First, although results from numerous studies of natural products have demonstrated their inhibitory role in Hh signaling, many have not been proven to be direct inhibitors of the $\mathrm{Hh}$ signaling molecules. Because Hh signaling can be modulated by both canonical regulation and interaction with different cellular pathways, it is critical to conduct detailed investigations using appropriate in vitro and in vivo models to identify the natural components' direct cellular targets. Second, many natural products are poorly bioavailable and metabolized by the intestinal microflora and/or hepatic metabolizing enzymes. In addition, the concentrations used in some in vitro studies may not be achievable in physiological conditions. Therefore, the natural products' blood levels necessary for activity need to be determined. Third, experience from clinical trials with Smo-targeted drugs showed the importance of selecting cancer patients with aberrantly activated Hh pathway to achieve tumor response. Thus, it is important to systematically characterize the Hh signaling profiles in cancer cells and in animal tumor models. Fourth, combining natural products to maximize inhibition of $\mathrm{Hh}$ signaling may be necessary to provide optimal efficacy while overcoming resistance.

Overall, despite the outlined challenges, exploring natural products and dietary components that target the complex network of signaling molecules in the Hh pathway is a promising direction in the effort of searching for novel agents to prevent and treat cancer.

\section{Acknowledgments}

The work was in part supported by the National Center for Complementary and Integrative Health of the National Institutes of Health under Award Number R01 AT007036, the National Institute of Environmental Health Sciences grant ES005022, Charles and Johanna Busch Memorial Fund at Rutgers University, the Trustees Research Fellowship Program at Rutgers, and the National Research Foundation of Korea (NRF) grant funded by the Korea government (MSIP) (NRF-2017R1A2B4010685). The content is solely the responsibility of the authors and does not necessarily represent the official views of the National Institutes of Health.

\section{Abbreviations:}

$\begin{array}{ll}\text { ALDH } & \text { aldehyde dehydrogenase } \\ \text { BCC } & \text { basal cell carcinoma } \\ \text { CDON } & \text { cell adhesion molecule-related/down-regulated by oncogenes } \\ \text { CK } & \text { casein kinase } \\ \text { CSC } & \text { cancer stem cells }\end{array}$




\begin{tabular}{|c|c|}
\hline CXCR4 & chemokine receptor 4 \\
\hline Dhh & Desert Hedgehog \\
\hline EMT & epithelial-mesenchymal transition \\
\hline ERK & extracellular signal-regulated kinase \\
\hline GANT & Gli antagonist \\
\hline Gli & glioma associated oncogene \\
\hline GSK & glycogen synthase kinase \\
\hline Hh & Hedgehog \\
\hline Ihh & Indian Hedgehog \\
\hline JNK & c-Jun N-terminal kinase \\
\hline LSC & leukemia stem cells \\
\hline MAPK & mitogen-activated protein kinase \\
\hline MEF & mouse embryonic fibroblasts \\
\hline MMP & matrix metalloproteinase \\
\hline MPF & mitosis promoting factor \\
\hline NF $\times B$ & nuclear factor- $\kappa \mathrm{B}$ \\
\hline PI3K & phosphatidylinositol-3-kinase \\
\hline PKA & protein kinase $\mathrm{A}$ \\
\hline S6K & S6 kinase \\
\hline SAG & Smo agonist \\
\hline Shh & Sonic Hedgehog \\
\hline Smo & Smoothened \\
\hline SuFu & suppressor of fused \\
\hline TGF & transforming growth factor \\
\hline TNF & tumor necrosis factor \\
\hline mTOR & mammalian target of rapamycin \\
\hline VEGF & vascular endothelial growth factor \\
\hline VDR & vitamin D receptor \\
\hline
\end{tabular}




\section{References}

[1]. Nusslein-Volhard C, Wieschaus E, Mutations affecting segment number and polarity in Drosophila. Nature 1980, 287, 795-801. [PubMed: 6776413]

[2]. Beachy PA, Karhadkar SS, Berman DM, Tissue repair and stem cell renewal in carcinogenesis. Nature 2004, 432, 324-331. [PubMed: 15549094]

[3]. Palma V, Altaba ARI, Hedgehog-GLI signaling regulates the behavior of cells with stem cell properties in the developing neocortex. Development 2004, 131, 337-345. [PubMed: 14681189]

[4]. Varjosalo M, Taipale J, Hedgehog: functions and mechanisms. Gene Dev. 2008, 22, 2454-2472. [PubMed: 18794343]

[5]. Bhardwaj G, Murdoch B, Wu D, Baker DP, Williams KP, Chadwick K, Ling LE, Karanu FN, Bhatia M, Sonic hedgehog induces the proliferation of primitive human hematopoietic cells via BMP regulation. Nat. immunol 2001, 2, 172-180. [PubMed: 11175816]

[6]. Ahn S, Joyner AL, In vivo analysis of quiescent adult neural stem cells responding to Sonic hedgehog. Nature 2005, 437, 894-897. [PubMed: 16208373]

[7]. Hahn H, Wicking C, Zaphiropoulous PG, Gailani MR, Shanley S, Chidambaram A, Vorechovsky I, Holmberg E, Unden AB, Gillies S, Negus K, Smyth I, Pressman C, Leffell DJ, Gerrard B, Goldstein AM, Dean M, Toftgard R, Chenevix-Trench G, Wainwright B, Bale AE, Mutations of the human homolog of Drosophila patched in the nevoid basal cell carcinoma syndrome. Cell 1996, 85, 841-851. [PubMed: 8681379]

[8]. Romer JT, Kimura H, Magdaleno S, Sasai K, Fuller C, Baines H, Connelly M, Stewart CF, Gould S, Rubin LL, Curran T, Suppression of the Shh pathway using a small molecule inhibitor eliminates medulloblastoma in Ptc1(+/-)p53(-/-) mice. Cancer Cell 2004, 6, 229-240. [PubMed: 15380514]

[9]. Wu F, Zhang Y, Sun B, McMahon AP, Wang Y, Hedgehog Signaling: From Basic Biology to Cancer Therapy. Cell Chem. Biol 2017, 24, 252-280. [PubMed: 28286127]

[10]. Amakye D, Jagani Z, Dorsch M, Unraveling the therapeutic potential of the Hedgehog pathway in cancer. Nat. Med 2013, 19, 1410-1422. [PubMed: 24202394]

[11]. Gonnissen A, Isebaert S, Haustermans K, Targeting the Hedgehog signaling pathway in cancer: beyond Smoothened. Oncotarget 2015, 6, 13899-13913. [PubMed: 26053182]

[12]. Rimkus TK, Carpenter RL, Qasem S, Chan M, Lo HW, Targeting the Sonic Hedgehog Signaling Pathway: Review of Smoothened and GLI Inhibitors. Cancers 2016, 8, 22.

[13]. Chang AL, Oro AE, Initial assessment of tumor regrowth after vismodegib in advanced Basal cell carcinoma. Arch. Dermatol 2012, 148, 1324-1325. [PubMed: 22910979]

[14]. Yauch RL, Dijkgraaf GJ, Alicke B, Januario T, Ahn CP, Holcomb T, Pujara K, Stinson J, Callahan CA, Tang T, Bazan JF, Kan Z, Seshagiri S, Hann CL, Gould SE, Low JA, Rudin CM, de Sauvage FJ, Smoothened mutation confers resistance to a Hedgehog pathway inhibitor in medulloblastoma. Science 2009, 326, 572-574. [PubMed: 19726788]

[15]. Drenkhahn SK, Jackson GA, Slusarz A, Starkey NJ, Lubahn DB, Inhibition of hedgehog/Gli signaling by botanicals: a review of compounds with potential hedgehog pathway inhibitory activities. Curr. Cancer Drug Targets 2013, 13, 580-595. [PubMed: 23675897]

[16]. Mayank Jaitak, V., Molecular docking study of natural alkaloids as multi-targeted hedgehog pathway inhibitors in cancer stem cell therapy. Comput. Biol. Chem 2016, 62, 145-154. [PubMed: 26278973]

[17]. Carpenter D, Stone DM, Brush J, Ryan A, Armanini M, Frantz G, Rosenthal A, de Sauvage FJ, Characterization of two patched receptors for the vertebrate hedgehog protein family. Proc. Natl. Acad. Sci. USA 1998, 95, 13630-13634. [PubMed: 9811851]

[18]. Marigo V, Davey RA, Zuo Y, Cunningham JM, Tabin CJ, Biochemical evidence that patched is the Hedgehog receptor. Nature 1996, 384, 176-179. [PubMed: 8906794]

[19]. Ingham PW, McMahon AP, Hedgehog signaling in animal development: paradigms and principles. Gene Dev. 2001, 15, 3059-3087. [PubMed: 11731473]

[20]. Barzi M, Berenguer J, Menendez A, Alvarez-Rodriguez R, Pons S, Sonic-hedgehog-mediated proliferation requires the localization of PKA to the cilium base. J. Cell Sci 2010, 123, 62-69. [PubMed: 20016067] 
[21]. Price MA, Kalderon D, Proteolysis of the Hedgehog signaling effector Cubitus interruptus requires phosphorylation by Glycogen Synthase Kinase 3 and Casein Kinase 1. Cell 2002, 108, 823-835. [PubMed: 11955435]

[22]. Tempe D, Casas M, Karaz S, Blanchet-Tournier MF, Concordet JP, Multisite protein kinase A and glycogen synthase kinase 3beta phosphorylation leads to Gli3 ubiquitination by SCFbetaTrCP. Mol. Cell. Biol 2006, 26, 4316-4326. [PubMed: 16705181]

[23]. Tuson M, He M, Anderson KV, Protein kinase A acts at the basal body of the primary cilium to prevent Gli2 activation and ventralization of the mouse neural tube. Development 2011, 138, 4921-4930. [PubMed: 22007132]

[24]. Mukhopadhyay S, Wen X, Ratti N, Loktev A, Rangell L, Scales SJ, Jackson PK, The ciliary Gprotein-coupled receptor Gpr161 negatively regulates the Sonic hedgehog pathway via cAMP signaling. Cell 2013, 152, 210-223. [PubMed: 23332756]

[25]. Corbit KC, Aanstad P, Singla V, Norman AR, Stainier DYR, Reiter JF, Vertebrate Smoothened functions at the primary cilium. Nature 2005, 437, 1018-1021. [PubMed: 16136078]

[26]. Huang P, Nedelcu D, Watanabe M, Jao C, Kim Y, Liu J, Salic A, Cellular Cholesterol Directly Activates Smoothened in Hedgehog Signaling. Cell 2016, 166, 1176-1187. [PubMed: 27545348]

[27]. Xiao X, Tang JJ, Peng C, Wang Y, Fu L, Qiu ZP, Xiong Y, Yang LF, Cui HW, He XL, Yin L, Qi W, Wong CC, Zhao Y, Li BL, Qiu WW, Song BL, Cholesterol Modification of Smoothened Is Required for Hedgehog Signaling. Mol. Cell 2017, 66, 154-162. [PubMed: 28344083]

[28]. Lee J, Platt KA, Censullo P, Ruiz i Altaba A, Gli1 is a target of Sonic hedgehog that induces ventral neural tube development. Development 1997, 124, 2537-2552. [PubMed: 9216996]

[29]. Kenney AM, Cole MD, Rowitch DH, Nmyc upregulation by sonic hedgehog signaling promotes proliferation in developing cerebellar granule neuron precursors. Development 2003, 130, 15-28. [PubMed: 12441288]

[30]. Kasper M, Schnidar H, Neill GW, Hanneder M, Klingler S, Blaas L, Schmid C, HauserKronberger C, Regl G, Philpott MP, Aberger F, Selective modulation of hedgehog/GLI target gene expression by epidermal growth factor signaling in human keratinocytes. Mol. Cell Biol 2006, 26, 6283-6298. [PubMed: 16880536]

[31]. Yoon JW, Kita Y, Frank DJ, Majewski RR, Konicek BA, Nobrega MA, Jacob H, Walterhouse D, Iannaccone P, Gene expression profiling leads to identification of GLI1-binding elements in target genes and a role for multiple downstream pathways in GLI1-induced cell transformation. J. Biol. Chem 2002, 277, 5548-5555. [PubMed: 11719506]

[32]. Teh MT, Blaydon D, Chaplin T, Foot NJ, Skoulakis S, Raghavan M, Harwood CA, Proby CM, Philpott MP, Young BD, Kelsell DP, Genomewide single nucleotide polymorphism microarray mapping in basal cell carcinomas unveils uniparental disomy as a key somatic event. Cancer Res. 2005, 65, 8597-8603. [PubMed: 16204023]

[33]. Eichberger T, Kaser A, Pixner C, Schmid C, Klingler S, Winklmayr M, Hauser-Kronberger C, Aberger F, Frischauf AM, GLI2-specific transcriptional activation of the bone morphogenetic protein/activin antagonist follistatin in human epidermal cells. J. Biol. Chem 2008, 283, 1242612437. [PubMed: 18319260]

[34]. Kump E, Ji J, Wernli M, Hausermann P, Erb P, Gli2 upregulates cFlip and renders basal cell carcinoma cells resistant to death ligand-mediated apoptosis. Oncogene 2008, 27, 3856-3864. [PubMed: 18264131]

[35]. Regl G, Kasper M, Schnidar H, Eichberger T, Neill GW, Philpott MP, Esterbauer H, HauserKronberger C, Frischauf AM, Aberger F, Activation of the BCL2 promoter in response to Hedgehog/GLI signal transduction is predominantly mediated by GLI2. Cancer Res. 2004, 64, 7724-7731. [PubMed: 15520176]

[36]. Dennler S, Andre J, Alexaki I, Li A, Magnaldo T, ten Dijke P, Wang XJ, Verrecchia F, Mauviel A, Induction of sonic hedgehog mediators by transforming growth factor-beta: Smad3-dependent activation of Gli2 and Gli1 expression in vitro and in vivo. Cancer Res. 2007, 67, 6981-6986. [PubMed: 17638910]

[37]. Riobo NA, Haines GM, Emerson CP Jr., Protein kinase C-delta and mitogen-activated protein/ extracellular signal-regulated kinase-1 control GLI activation in hedgehog signaling. Cancer Res. 2006, 66, 839-845. [PubMed: 16424016] 
[38]. Riobo NA, Lu K, Ai X, Haines GM, Emerson CP Jr., Phosphoinositide 3-kinase and Akt are essential for Sonic Hedgehog signaling. Proc. Natl. Acad. Sci. USA 2006, 103, 4505-4510. [PubMed: 16537363]

[39]. Wang Y, Ding Q, Yen CJ, Xia W, Izzo JG, Lang JY, Li CW, Hsu JL, Miller SA, Wang X, Lee DF, Hsu JM, Huo L, Labaff AM, Liu D, Huang TH, Lai CC, Tsai FJ, Chang WC, Chen CH, Wu TT, Buttar NS, Wang KK, Wu Y, Wang H, Ajani J, Hung MC, The crosstalk of mTOR/S6K1 and Hedgehog pathways. Cancer Cell 2012, 21, 374-387. [PubMed: 22439934]

[40]. Zhou J, Zhu G, Huang J, Li L, Du Y, Gao Y, Wu D, Wang X, Hsieh JT, He D, Wu K, Noncanonical GLI1/2 activation by PI3K/AKT signaling in renal cell carcinoma: A novel potential therapeutic target. Cancer Lett. 2016, 370, 313-323. [PubMed: 26577809]

[41]. Zinke J, Schneider FT, Harter PN, Thom S, Ziegler N, Toftgard R, Plate KH, Liebner S, betaCatenin-Gli1 interaction regulates proliferation and tumor growth in medulloblastoma. Mol. Cancer 2015, 14, 17. [PubMed: 25645196]

[42]. Rovida E, Stecca B, Mitogen-activated protein kinases and Hedgehog-GLI signaling in cancer: A crosstalk providing therapeutic opportunities? Semin. Cancer Biol 2015, 35, 154-167. [PubMed: 26292171]

[43]. Scales SJ, de Sauvage FJ, Mechanisms of Hedgehog pathway activation in cancer and implications for therapy. Trends Pharmacol. Sci 2009, 30, 303-312. [PubMed: 19443052]

[44]. Marelli G, Sica A, Vannucci L, Allavena P, Inflammation as target in cancer therapy. Curr. Opin. Pharmacol 2017, 35, 57-65. [PubMed: 28618326]

[45]. Kim JH, Choi YJ, Lee SH, Shin HS, Lee IO, Kim YJ, Kim H, Yang WI, Kim H, Lee YC, Effect of Helicobacter pylori infection on the sonic hedgehog signaling pathway in gastric cancer cells. Oncol. Rep 2010, 23, 1523-1528. [PubMed: 20428805]

[46]. Schumacher MA, Feng R, Aihara E, Engevik AC, Montrose MH, Ottemann KM, Zavros Y, Helicobacter pylori-induced Sonic Hedgehog expression is regulated by NFkappaB pathway activation: the use of a novel in vitro model to study epithelial response to infection. Helicobacter 2015, 20, 19-28. [PubMed: 25495001]

[47]. El-Zaatari M, Kao JY, Tessier A, Bai LC, Hayes MM, Fontaine C, Eaton KA, Merchant JL, Gli1 Deletion Prevents Helicobacter-Induced Gastric Metaplasia and Expansion of Myeloid Cell Subsets. PLoS one 2013, 8, e58935. [PubMed: 23520544]

[48]. Kwon H, Song K, Han C, Chen W, Wang Y, Dash S, Lim K, Wu T, Inhibition of hedgehog signaling ameliorates hepatic inflammation in mice with nonalcoholic fatty liver disease. Hepatology (Baltimore, Md.) 2016, 63, 1155-1169.

[49]. Kenney AM, Rowitch DH, Sonic hedgehog promotes G(1) cyclin expression and sustained cell cycle progression in mammalian neuronal precursors. Mol. Cell Biol. 2000, 20, 9055-9067. [PubMed: 11074003]

[50]. Mill P, Mo R, Fu H, Grachtchouk M, Kim PCW, Dlugosz AA, Hui CC, Sonic hedgehogdependent activation of Gli2 is essential for embryonic hair follicle development. Gene Dev. 2003, 17, 282-294. [PubMed: 12533516]

[51]. Lin Z, Sheng H, You C, Cai M, Zhang Y, Yu LS, Yu X, Lin J, Zhang N, Inhibition of the CyclinD1 promoter in response to sonic hedgehog signaling pathway transduction is mediated by Gli1. Exp. Ther. Med 2017, 13, 307-314. [PubMed: 28123507]

[52]. Barnes EA, Kong M, Ollendorff V, Donoghue DJ, Patched1 interacts with cyclin B1 to regulate cell cycle progression. EMBO J. 2001, 20, 2214-2223. [PubMed: 11331587]

[53]. Fan HR, Khavari PA, Sonic hedgehog opposes epithelial cell cycle arrest. J. Cell Biol 1999, 147, 71-76. [PubMed: 10508856]

[54]. Athar M, Li C, Tang X, Chi S, Zhang X, Kim AL, Tyring SK, Kopelovich L, Hebert J, Epstein EH Jr., Bickers DR, Xie J, Inhibition of smoothened signaling prevents ultraviolet B-induced basal cell carcinomas through regulation of Fas expression and apoptosis. Cancer Res. 2004, 64, 7545-7552. [PubMed: 15492281]

[55]. Delloye-Bourgeois C, Gibert B, Rama N, Delcros JG, Gadot N, Scoazec JY, Krauss R, Bernet A, Mehlen P, Sonic Hedgehog promotes tumor cell survival by inhibiting CDON pro-apoptotic activity. PLoS Biol. 2013, 11, e1001623. [PubMed: 23940460] 
[56]. Levitt RJ, Zhao Y, Blouin MJ, Pollak M, The hedgehog pathway inhibitor cyclopamine increases levels of p27, and decreases both expression of IGF-II and activation of Akt in PC-3 prostate cancer cells. Cancer Lett. 2007, 255, 300-306. [PubMed: 17602833]

[57]. Wu C, Hu S, Cheng J, Wang G, Tao K, Smoothened antagonist GDC-0449 (Vismodegib) inhibits proliferation and triggers apoptosis in colon cancer cell lines. Exp. Ther. Med 2017, 13, 25292536. [PubMed: 28565875]

[58]. Benvenuto M, Masuelli L, De Smaele E, Fantini M, Mattera R, Cucchi D, Bonanno E, Di Stefano E, Frajese GV, Orlandi A, Screpanti I, Gulino A, Modesti A, Bei R, In vitro and in vivo inhibition of breast cancer cell growth by targeting the Hedgehog/GLI pathway with SMO (GDC-0449) or GLI (GANT-61) inhibitors. Oncotarget 2016, 7, 9250-9270. [PubMed: 26843616]

[59]. Maj E, Papiernik D, Wietrzyk J, Antiangiogenic cancer treatment: The great discovery and greater complexity (Review). Int. J. Oncol 2016, 49, 1773-1784. [PubMed: 27826619]

[60]. Cao X, Geradts J, Dewhirst MW, Lo HW, Upregulation of VEGF-A and CD24 gene expression by the tGLI1 transcription factor contributes to the aggressive behavior of breast cancer cells. Oncogene 2012, 31, 104-115. [PubMed: 21666711]

[61]. Di Mauro C, Rosa R, D’Amato V, Ciciola P, Servetto A, Marciano R, Orsini RC, Formisano L, De Falco S, Cicatiello V, Di Bonito M, Cantile M, Collina F, Chambery A, Veneziani BM, De Placido S, Bianco R, Hedgehog signalling pathway orchestrates angiogenesis in triple-negative breast cancers. Br. J. Cancer 2017, 116, 1425-1435. [PubMed: 28441382]

[62]. Li W, Miao S, Miao M, Li R, Cao X, Zhang K, Huang G, Fu B, Hedgehog Signaling Activation in Hepatic Stellate Cells Promotes Angiogenesis and Vascular Mimicry in Hepatocellular Carcinoma. Cancer Invest. 2016, 34, 424-430. [PubMed: 27657189]

[63]. Chen W, Tang T, Eastham-Anderson J, Dunlap D, Alicke B, Nannini M, Gould S, Yauch R, Modrusan Z, DuPree KJ, Darbonne WC, Plowman G, de Sauvage FJ, Callahan CA, Canonical hedgehog signaling augments tumor angiogenesis by induction of VEGF-A in stromal perivascular cells. Proc. Natl. Acad. Sci. USA 2011, 108, 9589-9594. [PubMed: 21597001]

[64]. Harris LG, Pannell LK, Singh S, Samant RS, Shevde LA, Increased vascularity and spontaneous metastasis of breast cancer by hedgehog signaling mediated upregulation of cyr61. Oncogene 2012, 31, 3370-3380. [PubMed: 22056874]

[65]. Brown GT, Murray GI, Current mechanistic insights into the roles of matrix metalloproteinases in tumour invasion and metastasis. J. Pathol 2015, 237, 273-281. [PubMed: 26174849]

[66]. Inaguma S, Riku M, Ito H, Tsunoda T, Ikeda H, Kasai K, GLI1 orchestrates CXCR4/CXCR7 signaling to enhance migration and metastasis of breast cancer cells. Oncotarget 2015, 6, 3364833657. [PubMed: 26413813]

[67]. Bao C, Namgung H, Lee J, Park HC, Ko J, Moon H, Ko HW, Lee HJ, Daidzein suppresses tumor necrosis factor-alpha induced migration and invasion by inhibiting hedgehog/Gli1 signaling in human breast cancer cells. J. Agric. Food Chem 2014, 62, 3759-3767. [PubMed: 24724627]

[68]. Yoo YA, Kang MH, Lee HJ, Kim BH, Park JK, Kim HK, Kim JS, Oh SC, Sonic hedgehog pathway promotes metastasis and lymphangiogenesis via activation of Akt, EMT, and MMP-9 pathway in gastric cancer. Cancer Res. 2011, 71, 7061-7070. [PubMed: 21975935]

[69]. Chong Y, Tang D, Gao J, Jiang X, Xu C, Xiong Q, Huang Y, Wang J, Zhou H, Shi Y, Wang D, Galectin-1 induces invasion and the epithelial-mesenchymal transition in human gastric cancer cells via non-canonical activation of the hedgehog signaling pathway. Oncotarget 2016, 7, 83611-83626. [PubMed: 27835885]

[70]. Chang L, Zhao D, Liu HB, Wang QS, Zhang P, Li CL, Du WZ, Wang HJ, Liu X, Zhang ZR, Jiang CL, Activation of sonic hedgehog signaling enhances cell migration and invasion by induction of matrix metalloproteinase- 2 and -9 via the phosphoinositide- 3 kinase/AKT signaling pathway in glioblastoma. Mol. Med. Rep 2015, 12, 6702-6710. [PubMed: 26299938]

[71]. Chang JC, Cancer stem cells: Role in tumor growth, recurrence, metastasis, and treatment resistance. Medicine (Baltimore) 2016, 95, S20-25. [PubMed: 27611935]

[72]. Cochrane CR, Szczepny A, Watkins DN, Cain JE, Hedgehog Signaling in the Maintenance of Cancer Stem Cells. Cancers 2015, 7, 1554-1585. [PubMed: 26270676]

[73]. Balbous A, Renoux B, Cortes U, Milin S, Guilloteau K, Legigan T, Rivet P, Boissonnade O, Martin S, Tripiana C, Wager M, Bensadoun RJ, Papot S, Karayan-Tapon L, Selective release of a 
cyclopamine glucuronide prodrug toward stem-like cancer cell inhibition in glioblastoma. Mol. Cancer Ther 2014, 13, 2159-2169. [PubMed: 25053823]

[74]. Liu SL, Dontu G, Mantle ID, Patel S, Ahn NS, Jackson KW, Suri P, Wicha MS, Hedgehog signaling and Bmi-1 regulate self-renewal of normal and malignant human mammary stem cells. Cancer Res. 2006, 66, 6063-6071. [PubMed: 16778178]

[75]. Varnat F, Duquet A, Malerba M, Zbinden M, Mas C, Gervaz P, Altaba ARI, Human colon cancer epithelial cells harbour active HEDGEHOG-GLI signalling that is essential for tumour growth, recurrence, metastasis and stem cell survival and expansion. EMBO Mol. Med 2009, 1, 338-351. [PubMed: 20049737]

[76]. Wang F, Ma L, Zhang Z, Liu X, Gao H, Zhuang Y, Yang P, Kornmann M, Tian X, Yang Y, Hedgehog Signaling Regulates Epithelial-Mesenchymal Transition in Pancreatic Cancer StemLike Cells. J. Cancer 2016, 7, 408-417. [PubMed: 26918054]

[77]. Dierks C, Beigi R, Guo GR, Zirlik K, Stegert MR, Manley P, Trussell C, Schmitt-Graeff A, Landwerlin K, Veelken H, Warmuth M, Expansion of Bcr-Abl-positive leukemic stem cells is dependent on hedgehog pathway activation. Cancer Cell 2008, 14, 238-249. [PubMed: 18772113]

[78]. Wang J, Peng YQ, Liu Y, Yang J, Ding N, Tan WF, Berberine, a natural compound, suppresses Hedgehog signaling pathway activity and cancer growth. BMC Cancer 2015, 15, 595. [PubMed: 26296751]

[79]. Chen JK, Taipale J, Cooper MK, Beachy PA, Inhibition of Hedgehog signaling by direct binding of cyclopamine to Smoothened. Genes Dev. 2002, 16, 2743-2748. [PubMed: 12414725]

[80]. Mahindroo N, Punchihewa C, Fujii N, Hedgehog-Gli signaling pathway inhibitors as anticancer agents. J. Med. Chem 2009, 52, 3829-3845. [PubMed: 19309080]

[81]. Berman DM, Karhadkar SS, Hallahan AR, Pritchard JI, Eberhart CG, Watkins DN, Chen JK, Cooper MK, Taipale J, Olson JM, Beachy PA, Medulloblastoma growth inhibition by hedgehog pathway blockade. Science 2002, 297, 1559-1561. [PubMed: 12202832]

[82]. Feldmann G, Dhara S, Fendrich V, Bedja D, Beaty R, Mullendore M, Karikari C, Alvarez H, Iacobuzio-Donahue C, Jimeno A, Gabrielson KL, Matsui W, Maitra A, Blockade of hedgehog signaling inhibits pancreatic cancer invasion and metastases: a new paradigm for combination therapy in solid cancers. Cancer Res. 2007, 67, 2187-2196. [PubMed: 17332349]

[83]. Sanchez P, Ruiz i Altaba A, In vivo inhibition of endogenous brain tumors through systemic interference of Hedgehog signaling in mice. Mech. Dev 2005, 122, 223-230. [PubMed: 15652709]

[84]. Stecca B, Mas C, Clement V, Zbinden M, Correa R, Piguet V, Beermann F, Ruiz IAA, Melanomas require HEDGEHOG-GLI signaling regulated by interactions between GLI1 and the RAS-MEK/AKT pathways. Proc. Natl. Acad. Sci. USA 2007, 104, 5895-5900. [PubMed: 17392427]

[85]. Tabs S, Avci O, Induction of the differentiation and apoptosis of tumor cells in vivo with efficiency and selectivity. Eur. J. Dermatol 2004, 14, 96-102. [PubMed: 15196999]

[86]. Von Hoff DD, LoRusso PM, Rudin CM, Reddy JC, Yauch RL, Tibes R, Weiss GJ, Borad MJ, Hann CL, Brahmer JR, Mackey HM, Lum BL, Darbonne WC, Marsters JC, de Sauvage FJ, Low JA, Inhibition of the Hedgehog Pathway in Advanced Basal-Cell Carcinoma. New Engl. J. Med 2009, 361, 1164-1172. [PubMed: 19726763]

[87]. Tremblay MR, Lescarbeau A, Grogan MJ, Tan E, Lin G, Austad BC, Yu LC, Behnke ML, Nair SJ, Hagel M, White K, Conley J, Manna JD, Alvarez-Diez TM, Hoyt J, Woodward CN, Sydor JR, Pink M, MacDougall J, Campbell MJ, Cushing J, Ferguson J, Curtis MS, McGovern K, Read MA, Palombella VJ, Adams J, Castro AC, Discovery of a potent and orally active hedgehog pathway antagonist (IPI-926). J.Med. Chem 2009, 52, 4400-4418. [PubMed: 19522463]

[88]. Lee ST, Welch KD, Panter KE, Gardner DR, Garrossian M, Chang CW, Cyclopamine: from cyclops lambs to cancer treatment. J. Agric. Food Chem 2014, 62, 7355-7362. [PubMed: 24754790]

[89]. Rudin CM, Vismodegib. Clin. Cancer Res 2012, 18, 3218-3222. [PubMed: 22679179]

[90]. Burness CB, Sonidegib: First Global Approval. Drugs 2015, 75, 1559-1566. [PubMed: 26323341] 
[91]. Infante P, Mori M, Alfonsi R, Ghirga F, Aiello F, Toscano S, Ingallina C, Siler M, Cucchi D, Po A, Miele E, D'Amico D, Canettieri G, De Smaele E, Ferretti E, Screpanti I, Uccello Barretta G, Botta M, Botta B, Gulino A, Di Marcotullio L, Gli1/DNA interaction is a druggable target for Hedgehog-dependent tumors. EMBO J. 2015, 34, 200-217. [PubMed: 25476449]

[92]. Bijlsma MF, Peppelenbosch MP, Spek CA, (Pro-) vitamin D as treatment option for hedgehogrelated malignancies. Med. Hypotheses 2008, 70, 202-203. [PubMed: 17870251]

[93]. Banerjee U, Ghosh M, Kyle Hadden M, Evaluation of vitamin D3 A-ring analogues as Hedgehog pathway inhibitors. Bioorg. Med. Chem. Lett 2012, 22, 1330-1334. [PubMed: 22226657]

[94]. Deberardinis AM, Madden DJ, Banerjee U, Sail V, Raccuia DS, De Carlo D, Lemieux SM, Meares A, Hadden MK, Structure-activity relationships for vitamin D3-based aromatic a-ring analogues as hedgehog pathway inhibitors. J. Med. Chem 2014, 57, 3724-3736. [PubMed: 24730984]

[95]. Tang JY, Xiao TZ, Oda Y, Chang KS, Shpall E, Wu A, So PL, Hebert J, Bikle D, Epstein EH Jr., Vitamin D3 inhibits hedgehog signaling and proliferation in murine Basal cell carcinomas. Cancer Prev. Res. (Phila) 2011, 4, 744-751. [PubMed: 21436386]

[96]. Dormoy V, Beraud C, Lindner V, Coquard C, Barthelmebs M, Brasse D, Jacqmin D, Lang H, Massfelder T, Vitamin D3 triggers antitumor activity through targeting hedgehog signaling in human renal cell carcinoma. Carcinogenesis 2012, 33, 2084-2093. [PubMed: 22843547]

[97]. Uhmann A, Niemann H, Lammering B, Henkel C, Hess I, Nitzki F, Fritsch A, Prufer N, Rosenberger A, Dullin C, Schraepler A, Reifenberger J, Schweyer S, Pietsch T, Strutz F, SchulzSchaeffer W, Hahn H, Antitumoral effects of calcitriol in basal cell carcinomas involve inhibition of hedgehog signaling and induction of vitamin D receptor signaling and differentiation. Mol. Cancer Ther. 2011, 10, 2179-2188. [PubMed: 21878656]

[98]. Alimirah F, Peng XJ, Gupta A, Yuan L, Welsh J, Cleary M, Mehta RG, Crosstalk between the vitamin D receptor (VDR) and miR-214 in regulating $\mathrm{SuFu}$, a hedgehog pathway inhibitor in breast cancer cells. Exp. Cell Res 2016, 349, 15-22. [PubMed: 27693451]

[99]. Du WZ, Feng Y, Wang XF, Piao XY, Cui YQ, Chen LC, Lei XH, Sun X, Liu X, Wang HB, Li XF, Yang DB, Sun Y, Zhao ZF, Jiang T, Li YL, Jiang CL, Curcumin suppresses malignant glioma cells growth and induces apoptosis by inhibition of SHH/GLI1 signaling pathway in vitro and vivo. CNS Neurosci. Ther 2013, 19, 926-936. [PubMed: 24165291]

[100]. Elamin MH, Shinwari Z, Hendrayani SF, Al-Hindi H, Al-Shail E, Khafaga Y, Al-Kofide A, Aboussekhra A, Curcumin inhibits the Sonic Hedgehog signaling pathway and triggers apoptosis in medulloblastoma cells. Mol. Carcinog 2010, 49, 302-314. [PubMed: 20025076]

[101]. Slusarz A, Shenouda NS, Sakla MS, Drenkhahn SK, Narula AS, MacDonald RS, BeschWilliford CL, Lubahn DB, Common botanical compounds inhibit the hedgehog signaling pathway in prostate cancer. Cancer Res. 2010, 70, 3382-3390. [PubMed: 20395211]

[102]. Cao L, Xiao X, Lei J, Duan W, Ma Q, Li W, Curcumin inhibits hypoxia-induced epithelialmesenchymal transition in pancreatic cancer cells via suppression of the hedgehog signaling pathway. Oncol. Rep 2016, 35, 3728-3734. [PubMed: 27035865]

[103]. Sun XD, Liu XE, Huang DS, Curcumin reverses the epithelial-mesenchymal transition of pancreatic cancer cells by inhibiting the Hedgehog signaling pathway. Oncol. Rep 2013, 29, 2401-2407. [PubMed: 23563640]

[104]. Meng X, Cai J, Liu J, Han B, Gao F, Gao W, Zhang Y, Zhang J, Zhao Z, Jiang C, Curcumin increases efficiency of gamma-irradiation in gliomas by inhibiting Hedgehog signaling pathway. Cell Cycle 2017, 16, 1181-1192. [PubMed: 28463091]

[105]. Zhu JY, Yang X, Chen Y, Jiang Y, Wang SJ, Li Y, Wang XQ, Meng Y, Zhu MM, Ma X, Huang C, Wu R, Xie CF, Li XT, Geng SS, Wu JS, Zhong CY, Han HY, Curcumin Suppresses Lung Cancer Stem Cells via Inhibiting Wnt/beta-catenin and Sonic Hedgehog Pathways. Phytother. Res 2017, 31, 680-688. [PubMed: 28198062]

[106]. Tang GQ, Yan TQ, Guo W, Ren TT, Peng CL, Zhao H, Lu XC, Zhao FL, Han X, (-)Epigallocatechin-3-gallate induces apoptosis and suppresses proliferation by inhibiting the human Indian Hedgehog pathway in human chondrosarcoma cells. J. Cancer Res. Clin. Oncol 2010, 136, 1179-1185. [PubMed: 20127255] 
[107]. Tang SN, Fu J, Nall D, Rodova M, Shankar S, Srivastava RK, Inhibition of sonic hedgehog pathway and pluripotency maintaining factors regulate human pancreatic cancer stem cell characteristics. Int. J. Cancer 2012, 131, 30-40. [PubMed: 21796625]

[108]. Sur S, Pal D, Mandal S, Roy A, Panda CK, Tea polyphenols epigallocatechin gallete and theaflavin restrict mouse liver carcinogenesis through modulation of self-renewal Wnt and hedgehog pathways. J. Nutr. Biochem 2016, 27, 32-42. [PubMed: 26386739]

[109]. Sur S, Pal D, Roy R, Barua A, Roy A, Saha P, Panda CK, Tea polyphenols EGCG and TF restrict tongue and liver carcinogenesis simultaneously induced by $\mathrm{N}$-nitrosodiethylamine in mice. Toxicol. Appl. Pharmacol 2016, 300, 34-46. [PubMed: 27058323]

[110]. Zhang L, Li L, Jiao M, Wu D, Wu K, Li X, Zhu G, Yang L, Wang X, Hsieh JT, He D, Genistein inhibits the stemness properties of prostate cancer cells through targeting Hedgehog-Gli1 pathway. Cancer Lett. 2012, 323, 48-57. [PubMed: 22484470]

[111]. Fan P, Fan S, Wang H, Mao J, Shi Y, Ibrahim MM, Ma W, Yu X, Hou Z, Wang B, Li L, Genistein decreases the breast cancer stem-like cell population through Hedgehog pathway. Stem Cell Res. Ther 2013, 4, 146. [PubMed: 24331293]

[112]. Yu D, Shin H-S, Lee YS, Lee D, Kim S, Lee YC, Genistein attenuates cancer stem cell characteristics in gastric cancer through the downregulation of Gli1. Oncol. Rep 2014, 31, 673678. [PubMed: 24297371]

[113]. Qin Y, Ma Z, Dang X, Li W, Ma Q, Effect of resveratrol on proliferation and apoptosis of human pancreatic cancer MIA PaCa-2 cells may involve inhibition of the Hedgehog signaling pathway. Mol. Med. Rep 2014, 10, 2563-2567. [PubMed: 25190613]

[114]. Gao Q, Yuan Y, Gan HZ, Peng Q, Resveratrol inhibits the hedgehog signaling pathway and epithelial-mesenchymal transition and suppresses gastric cancer invasion and metastasis. Oncol. Lett 2015, 9, 2381-2387. [PubMed: 26137075]

[115]. Li W, Cao L, Chen X, Lei J, Ma Q, Resveratrol inhibits hypoxia-driven ROS-induced invasive and migratory ability of pancreatic cancer cells via suppression of the Hedgehog signaling pathway. Oncol. Rep 2016, 35, 1718-1726. [PubMed: 26707376]

[116]. Ma ZK, Liu W, Zeng J, Zhou JC, Guo P, Xie HJ, Yang Z, Zheng L, Xu S, Wang XY, Chang L, He DL, Li L, Silibinin induces apoptosis through inhibition of the mTOR-GLI1-BCL2 pathway in renal cell carcinoma. Oncol. Rep 2015, 34, 2461-2468. [PubMed: 26323996]

[117]. Dheeraj A, Rigby CM, O'Bryant CL, Agarwal C, Singh RP, Deep G, Agarwal R, Silibinin Treatment Inhibits the Growth of Hedgehog Inhibitor-Resistant Basal Cell Carcinoma Cells via Targeting EGFR-MAPK-Akt and Hedgehog Signaling. Photochem. Photobiol 2017, 93, 9991007. [PubMed: 28120452]

[118]. Rodova M, Fu J, Watkins DN, Srivastava RK, Shankar S, Sonic hedgehog signaling inhibition provides opportunities for targeted therapy by sulforaphane in regulating pancreatic cancer stem cell self-renewal. PLoS one 2012, 7, e46083. [PubMed: 23029396]

[119]. Li SH, Fu J, Watkins DN, Srivastava RK, Shankar S, Sulforaphane regulates self-renewal of pancreatic cancer stem cells through the modulation of Sonic hedgehog-GLI pathway. Mol. Cell. Biochem 2013, 373, 217-227. [PubMed: 23129257]

[120]. Bao C, Kim MC, Chen J, Song J, Ko HW, Lee HJ, Sulforaphene Interferes with Human Breast Cancer Cell Migration and Invasion through Inhibition of Hedgehog Signaling. J. Agric. Food Chem 2016, 64, 5515-5524. [PubMed: 27327035]

[121]. Sung B, Jhurani S, Ahn KS, Mastuo Y, Yi T, Guha S, Liu M, Aggarwal BB, Zerumbone downregulates chemokine receptor CXCR4 expression leading to inhibition of CXCL12-induced invasion of breast and pancreatic tumor cells. Cancer Res. 2008, 68, 8938-8944. [PubMed: 18974138]

[122]. Subramani R, Gonzalez E, Nandy SB, Arumugam A, Camacho F, Medel J, Alabi D, Lakshmanaswamy R, Gedunin inhibits pancreatic cancer by altering sonic hedgehog signaling pathway. Oncotarget 2017, 8, 10891-10904. [PubMed: 26988754]

[123]. Rifai Y, Arai MA, Koyano T, Kowithayakorn T, Ishibashi M, Terpenoids and a flavonoid glycoside from Acacia pennata leaves as hedgehog/GLI-mediated transcriptional inhibitors. J. Nat. Prod 2010, 73, 995-997. [PubMed: 20450170] 
[124]. Hosoya T, Arai MA, Koyano T, Kowithayakorn T, Ishibashi M, Naturally occurring smallmolecule inhibitors of hedgehog/GLI-mediated transcription. Chembiochem 2008, 9, 1082-1092. [PubMed: 18357592]

[125]. Arai MA, Tateno C, Hosoya T, Koyano T, Kowithayakorn T, Ishibashi M, Hedgehog/GLImediated transcriptional inhibitors from Zizyphus cambodiana. Bioorg. Med. Chem 2008, 16, 9420-9424. [PubMed: 18842418]

[126]. Rifai Y, Arai MA, Koyano T, Kowithayakorn T, Ishibashi M, Acoschimperoside P, 2 '-acetate: a Hedgehog signaling inhibitory constituent from Vallaris glabra. J. Nat. Med 2011, 65, 629-632. [PubMed: 21625949]

[127]. Arai MA, Fujimatsu T, Uchida K, Sadhu SK, Ahmed F, Ishibashi M, Hh signaling inhibitors from Vitex negundo; naturally occurring inhibitors of the GLI1-DNA complex. Mol. Biosyst 2013, 9, 1012-1018. [PubMed: 23403897]

[128]. Arai MA, Uchida K, Sadhu SK, Ahmed F, Ishibashi M, Physalin H from Solanum nigrum as an Hh signaling inhibitor blocks GLI1-DNA-complex formation. Beilstein J. Org. Chem 2014, 10, 134-140. [PubMed: 24454566]

[129]. Arai MA, Tateno C, Koyano T, Kowithayakorn T, Kawabe S, Ishibashi M, New hedgehog/GLIsignaling inhibitors from Adenium obesum. Org. Biomol. Chem 2011, 9, 1133-1139. [PubMed: 21170436]

[130]. Zheng W, Lu S, Cai H, Kang M, Qin W, Li C, Wu Y, Deguelin inhibits proliferation and migration of human pancreatic cancer cells in vitro targeting hedgehog pathway. Oncol. Lett 2016, 12, 2761-2765. [PubMed: 27698853]

[131]. Zhao M, Tang SN, Marsh JL, Shankar S, Srivastava RK, Ellagic acid inhibits human pancreatic cancer growth in Balb c nude mice. Cancer Lett. 2013, 337, 210-217. [PubMed: 23684930]

[132]. Rangarajan P, Subramaniam D, Paul S, Kwatra D, Palaniyandi K, Islam S, Harihar S, Ramalingam S, Gutheil W, Putty S, Pradhan R, Padhye S, Welch DR, Anant S, Dhar A, Crocetinic acid inhibits hedgehog signaling to inhibit pancreatic cancer stem cells. Oncotarget 2015, 6, 27661-27673. [PubMed: 26317547]

[133]. Lee HJ, Wu Q, Li H, Bae GU, Kim AK, Ryu JH, A sesquiterpene lactone from Siegesbeckia glabrescens suppresses Hedgehog/Gli-mediated transcription in pancreatic cancer cells. Oncol. Lett 2016, 12, 2912-2917. [PubMed: 27698879]

[134]. Infante P, Alfonsi R, Ingallina C, Quaglio D, Ghirga F, D’Acquarica I, Bernardi F, Di Magno L, Canettieri G, Screpanti I, Gulino A, Botta B, Mori M, Di Marcotullio L, Inhibition of Hedgehogdependent tumors and cancer stem cells by a newly identified naturally occurring chemotype. Cell Death Dis. 2016, 7, e2376. [PubMed: 27899820]

[135]. Lin H, Jackson GA, Lu Y, Drenkhahn SK, Brownstein KJ, Starkey NJ, Lamberson WR, Fritsche KL, Mossine VV, Besch-Williford CL, Folk WR, Zhang Y, Lubahn DB, Inhibition of Gli/ hedgehog signaling in prostate cancer cells by "cancer bush" Sutherlandia frutescens extract. Cell Biol. Int 2016, 40, 131-142. [PubMed: 26377232] 


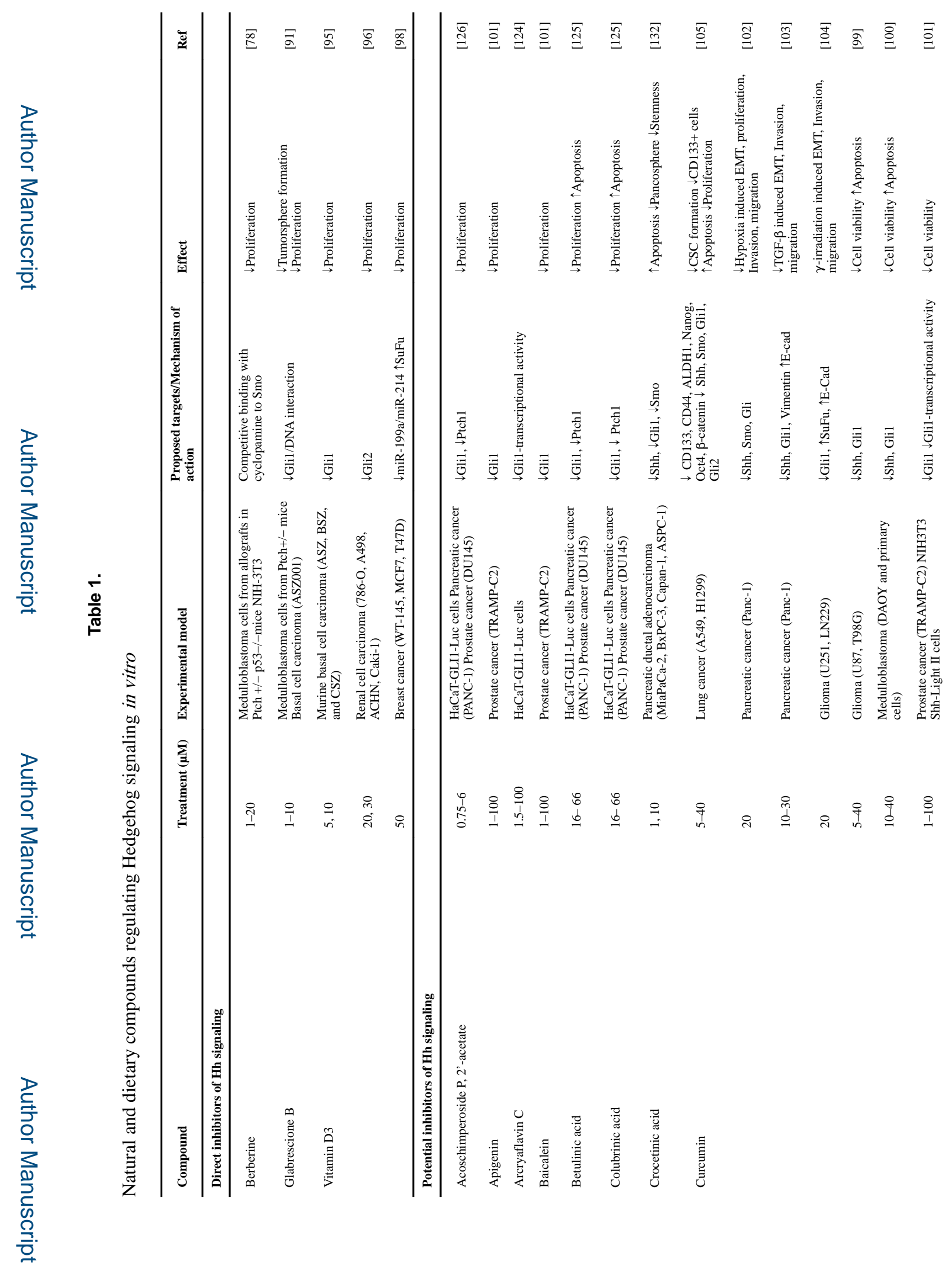

Mol Nutr Food Res. Author manuscript; available in PMC 2019 August 02. 
Bao et al.

Page 20

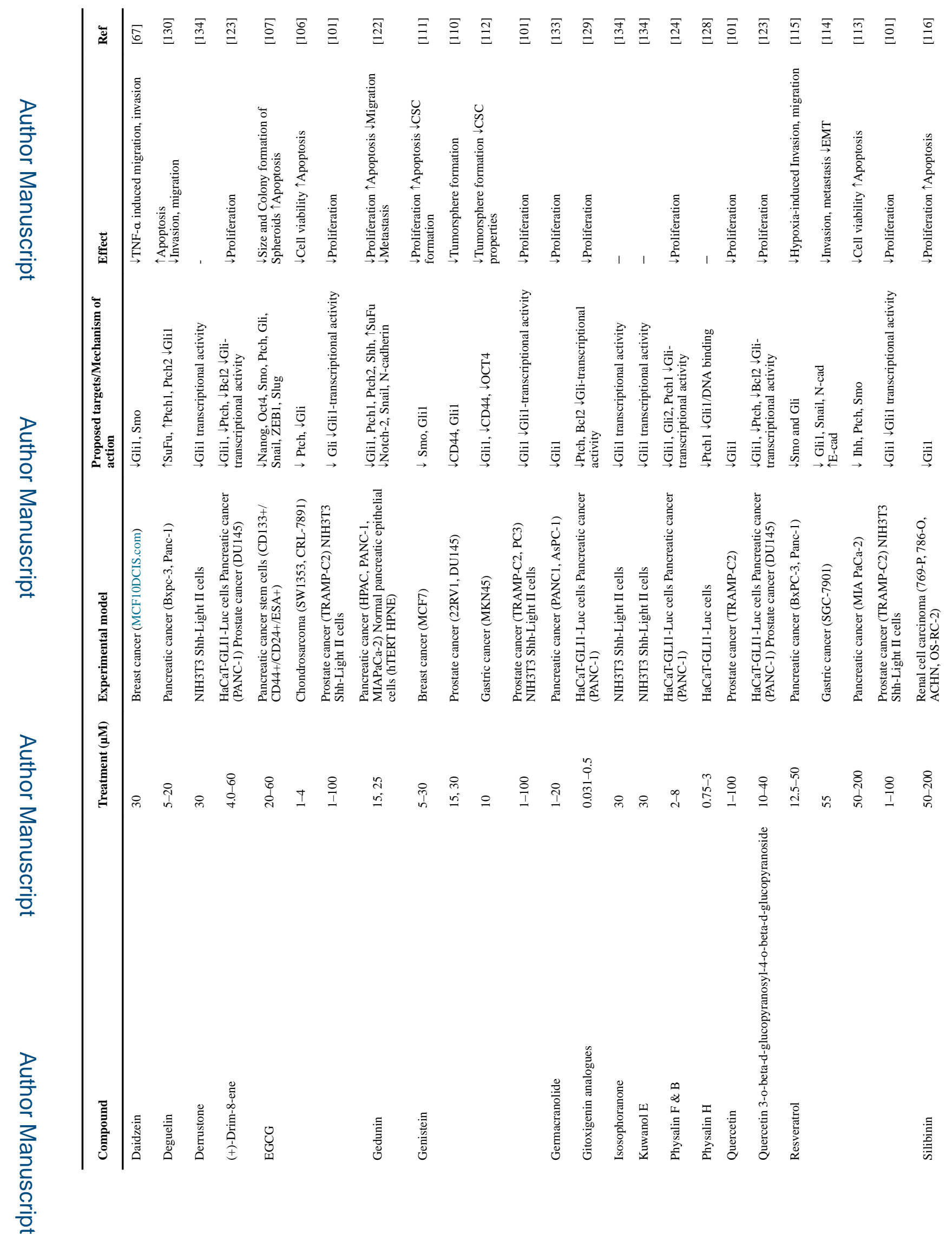

Mol Nutr Food Res. Author manuscript; available in PMC 2019 August 02. 
Bao et al.

Page 21

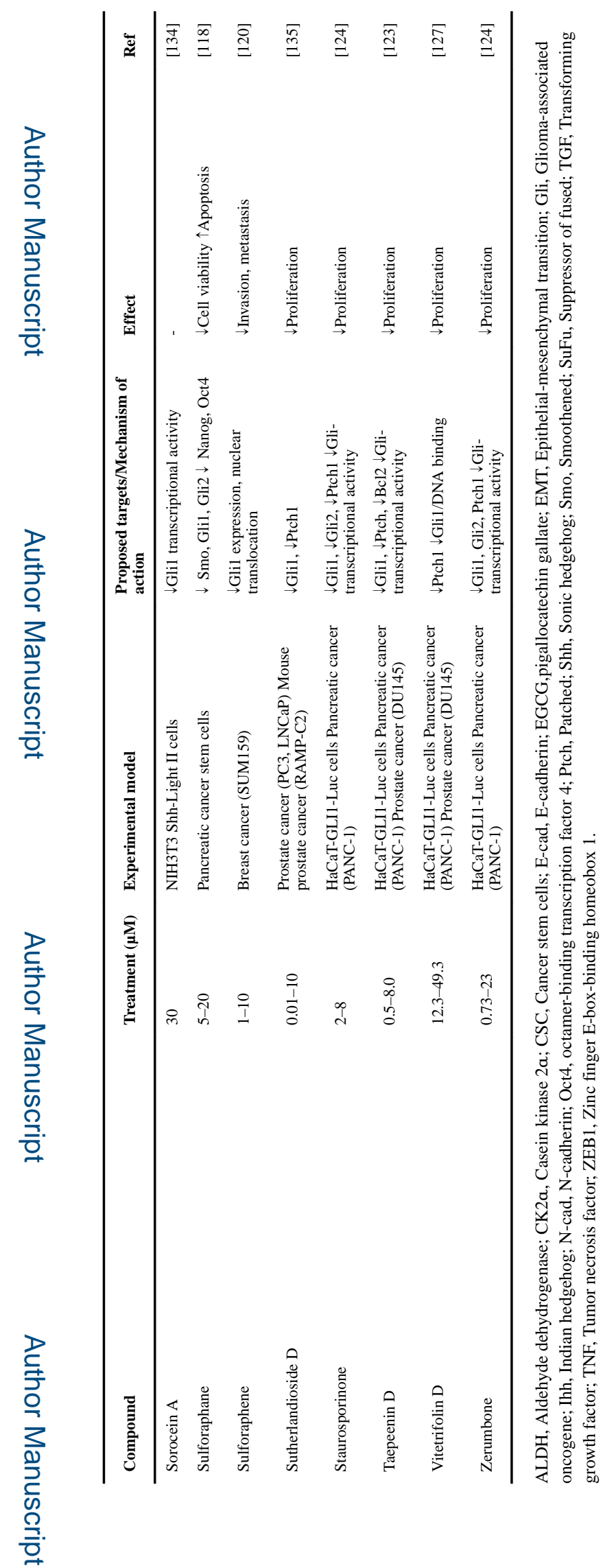

Mol Nutr Food Res. Author manuscript; available in PMC 2019 August 02. 
Table 2.

Natural and dietary compounds regulating Hedgehog signaling in vivo

\begin{tabular}{|c|c|c|c|c|}
\hline Compound & In vivo model & Treatment & Effect and Target & Ref \\
\hline Berberine & $\begin{array}{l}\text { Primary intracranial medulloblastoma } \\
\text { cells from Ptch }+/- \text { p } 53-/- \text { mouse s.c. in } \\
\text { athymic nude mice }\end{array}$ & $\begin{array}{l}100 \mathrm{mg} / \mathrm{kg} \mathrm{BW} \text {, p.o., daily for } \\
3 \text { weeks }\end{array}$ & $\begin{array}{l}\downarrow \text { Gli } 1, \downarrow \text { Ptch } \downarrow \text { Tumor growth } \\
\text { (37.5\% reduction) }\end{array}$ & {$[78]$} \\
\hline Curcumin & $\begin{array}{l}\text { U87-Luc }\left(3 \times 10^{5} \text { cells }\right) \text { intracranial } \\
\text { injection to female nude mice }\end{array}$ & $\begin{array}{l}60 \mathrm{mg} / \mathrm{kg} \mathrm{BW} \text {, i.p., daily for } \\
40 \text { days }\end{array}$ & $\begin{array}{l}\downarrow \text { Gli } 1 \downarrow \text { Tumor growth }(71.4 \% \\
\text { reduction) }\end{array}$ & {$[99]$} \\
\hline \multirow[t]{2}{*}{ EGCG } & $\begin{array}{l}\text { N-Nitrosodiethylamine (NDEA) into oral } \\
\text { cavity of female Swiss albino mice }\end{array}$ & $\begin{array}{l}8 \mu \mathrm{g} / \mathrm{kg} \text { BW, p.o., up to } 30 \\
\text { weeks }\end{array}$ & $\begin{array}{l}\downarrow \text { Gli1, Smo, CD } 44 \text {, Cyclin D1, c- } \\
\text { Myc, EGFR } \downarrow \text { BrdU incorporation } \\
\downarrow \text { Dysplasia progression }\end{array}$ & {$[109]$} \\
\hline & $\mathrm{CCl}_{4} / \mathrm{NDEA}$ in female Swiss albino mice & $\begin{array}{l}8 \mu \mathrm{g} / \mathrm{kg} \mathrm{BW}, \text { p.o., up to } 30 \\
\text { weeks }\end{array}$ & $\begin{array}{l}\uparrow \text { Ptch } 1 \downarrow \text { Smo, Gli1, CD } 44 \text { Cyclin } \\
\text { D1, c-Myc, EGFR } \downarrow \text { BrdU } \\
\text { incorporation } \downarrow \text { Dysplasia } \\
\text { progression }\end{array}$ & [108] \\
\hline Ellagic acid & $\begin{array}{l}\text { Pancreatic cancer cells PANC-1 } \\
\left(2 \times 10^{6} \text { cells }\right) \text { s.c. in BALB/c nude mice }\end{array}$ & $\begin{array}{l}40 \mathrm{mg} / \mathrm{kg} \mathrm{BW} \text {, p.o., } 5 \text { days a } \\
\text { week for } 6 \text { weeks }\end{array}$ & $\begin{array}{l}\downarrow \text { Gli1, Gli2 } \downarrow \text { Tumor growth and } \\
\text { metastasis ( } 41.2 \% \text { reduction) }\end{array}$ & [131] \\
\hline Gedunin & $\begin{array}{l}\text { Pancreatic cancer cells HPAC }\left(1 \times 10^{6}\right. \\
\text { cells) s.c. in female athymic nude mice }\end{array}$ & $\begin{array}{l}20 \mathrm{mg} / \mathrm{kg} \mathrm{BW} \text {, i.p., } 5 \text { days a } \\
\text { week for } 1 \text { month }\end{array}$ & $\begin{array}{l}\downarrow \text { Gli1, Ptch } 1, \text { Ptch } 2, \text { Shh } \uparrow \mathrm{SuFu} \\
\downarrow \text { Tumor growth }(82.2 \% \text { reduction })\end{array}$ & [122] \\
\hline \multirow[t]{3}{*}{ Genistein } & $\begin{array}{l}\text { Breast cancer cells MCF-7 }\left(1 \times 10^{6} \text { cells }\right) \text {, } \\
\text { mammary fat pad injection in female } \\
\text { nude mice }\end{array}$ & $\begin{array}{l}20 \text { and } 50 \mathrm{mg} / \mathrm{kg} \mathrm{BW} \text {, i.p., } \\
\text { daily for } 2 \text { weeks }\end{array}$ & $\begin{array}{l}\downarrow \text { Smo, Gli1, ALDH } \downarrow \text { Tumor growth } \\
\text { (46\% and } 68 \% \text { reduction, } \\
\text { respectively) }\end{array}$ & {$[111]$} \\
\hline & $\begin{array}{l}\text { Tumorsphere }\left(10^{4} \text { cells }\right) \text { from prostate } \\
\text { cancer cells } 22 \mathrm{RV} 1 \text { s.c. in male BALB/c } \\
\text { nude mice }\end{array}$ & $\begin{array}{l}10 \mathrm{mg} / \mathrm{kg} \mathrm{BW} \text {, i.p., daily for } 2 \\
\text { weeks }\end{array}$ & $\begin{array}{l}\downarrow \text { Gli } 1, \text { CD } 44 \downarrow \text { Tumor growth } \\
(58.3 \% \text { reduction) }\end{array}$ & {$[110]$} \\
\hline & $\begin{array}{l}\text { Tumorsphere }\left(10^{5} \text { cells }\right) \text { from prostate } \\
\text { cancer cells DU145 s.c. in male BALB/c } \\
\text { nude mice }\end{array}$ & $\begin{array}{l}10 \mathrm{mg} / \mathrm{kg} \mathrm{BW} \text {, i.p., daily for } 2 \\
\text { weeks }\end{array}$ & $\begin{array}{l}\downarrow \text { Gli } 1, \text { CD } 44 \downarrow \text { Tumor growth } \\
(57.1 \% \text { reduction })\end{array}$ & {$[110]$} \\
\hline \multirow[t]{2}{*}{ Glabrescione B } & $\begin{array}{l}\text { Medulloblastoma }\left(2 \times 10^{6} \text { cells }\right) \text { from Ptch } \\
+/- \text { mice s.c. in female BALB/c nude } \\
\text { mice }\end{array}$ & $\begin{array}{l}75 \mu \mathrm{mol} / \mathrm{kg} \mathrm{BW} \text {, daily for } 18 \\
\text { days }\end{array}$ & $\begin{array}{l}\downarrow \text { Gli } 1 \text {, Ptch } 1 \downarrow \text { Tumor growth } \\
\text { (63.6\% reduction) }\end{array}$ & {$[91]$} \\
\hline & $\begin{array}{l}\text { Basal cell carcinoma ASZ001 }\left(2 \times 10^{6}\right. \\
\text { cells }) \text { s.c. in female NOD/SCID mice }\end{array}$ & $\begin{array}{l}100 \mu \mathrm{mol} / \mathrm{kg} \mathrm{BW} \text {, daily for } 18 \\
\text { days }\end{array}$ & $\begin{array}{l}\downarrow \text { Gli1, PTCH } 1 \downarrow \text { Tumor growth } \\
\text { (71.4\% reduction) }\end{array}$ & {$[91]$} \\
\hline Silibinin & $\begin{array}{l}\text { Renal cell carcinoma } 786-O \text { cells s.c. in } \\
\text { male BALB/c nude mice }\end{array}$ & $\begin{array}{l}200 \mathrm{mg} / \mathrm{kg} \text {, p.o., daily for } 30 \\
\text { days }\end{array}$ & $\begin{array}{l}\downarrow \text { Gli } 1, \downarrow \text { Gli2 } \downarrow \text { Tumor growth } \\
\text { (64.9\% reduction) }\end{array}$ & {$[116]$} \\
\hline Sulforaphane & $\begin{array}{l}\text { Orthotopic implantation of pancreatic } \\
\text { cancer stem cells (CD } 133^{+} / \mathrm{CD} 44^{+} / \\
\mathrm{CD} 24^{+} / \mathrm{ESA}^{+}, 1 \times 10^{3} \text { cells) in the pancreas } \\
\text { of male NOD/SCID/IL } 2 \mathrm{R} \text { gamma mice }\end{array}$ & $\begin{array}{l}20 \mathrm{mg} / \mathrm{kg} \mathrm{BW} \text {, p.o. } 5 \text { days a } \\
\text { week for } 6 \text { weeks }\end{array}$ & $\begin{array}{l}\downarrow \text { Smo, Gli1, Gli2 } \downarrow \text { Nanog, Oct } 4, \\
\text { PDGFRa, VEGF, ZEB } 1 \uparrow \text { E-cad } \\
\downarrow \text { Tumor weight ( } 45.0 \% \text { reduction) }\end{array}$ & {$[119]$} \\
\hline \multirow[t]{3}{*}{ Vitamin D3 } & $\begin{array}{l}\text { Renal cell carcinoma 786-O cells s.c. in } \\
\text { male athymic nude mice }\end{array}$ & $\begin{array}{l}250 \mathrm{IU} / \mathrm{mouse}, \text { every } 2 \text { weeks, } \\
\text { i.p. Up to } 12 \text { weeks } \\
\text { (Prophylactic, therapeutic } \\
\text { treatment) }\end{array}$ & $\begin{array}{l}\downarrow \text { Gli2 } \downarrow \text { Tumor growth }(92.0 \% \text { and } \\
81.4 \% \text { reduction, respectively) }\end{array}$ & {$[96]$} \\
\hline & $\begin{array}{l}\text { Renal cell carcinoma } 786-O \text { cells s.c. in } \\
\text { male athymic nude mice }\end{array}$ & $\begin{array}{l}10,000 \mathrm{IU} / \mathrm{kg} \mathrm{BW} \text { diet. Up to } \\
12 \text { weeks (Prophylactic, } \\
\text { therapeutic treatment) }\end{array}$ & $\begin{array}{l}\downarrow \text { Gli2 } \downarrow \text { Tumor growth ( } 45.0 \% \text { and } \\
25.0 \% \text { reduction, respectively) }\end{array}$ & {$[96]$} \\
\hline & $\begin{array}{l}\text { Ionizing radiation treated Ptch1+/- K14- } \\
\text { Cre-ER p53 fl/fl mice developing basal } \\
\text { cell carcinoma }\end{array}$ & $\begin{array}{l}\text { Topical application of vitamin } \\
\text { D3 ( } 1.3 \text { and } 2.6 \mathrm{mg} / \mathrm{kg} \mathrm{BW}) \\
\text { up to } 30 \text { days }\end{array}$ & $\downarrow$ Gli1 $\downarrow$ Ki67 expression & [95] \\
\hline
\end{tabular}

ALDH, Aldehyde dehydrogenase; BW, Body weight; E-cad, E-cadherin; EGCG, Epigallocatechin gallate; EGFR, Epidermal growth factor receptor; Gli, Glioma-associated oncogene; i.p., intraperitoneal injection; Oct4, octamer-binding transcription factor 4; PDGFR, Platelet-derived growth factor receptor; p.o., per os (oral administration); Ptch, Patched; s.c., subcutaneous injection; Shh, Sonic hedgehog; Smo, Smoothened; SuFu, Suppressor of fused; VEGF, Vascular endothelial growth factor; ZEB1, Zinc finger E-box-binding homeobox 1. 